\title{
Visible morph-frequency variation in allopatric and sympatric populations of two species of Enoplognatha (Araneae: Theridiidae)
}

\author{
G. S. OXFORD \\ Department of Biology, University of York, York YO1 5DD, UK
}

\begin{abstract}
Samples were taken from single- and mixed-species populations of two spiders, Enoplognatha ovata and $E$. latimana, which share visible polymorphisms. The range of colour-morph frequencies was comparable between the species but $E$. latimana had a uniformly lower proportion of individuals with black spots. Spotted $E$. ovata females were more likely to have cocoons when collected than females without spots, although in spotted individuals there was no relationship between presence of cocoons and spot number. Colour-morph frequencies varied both within and between the seven study areas, sometimes over very short distances. A similar, though less marked, pattern was shown by the black spotting phenotype. This variation, on two geographical scales, was present in both species. No evidence was found for consistent shifts in morph frequencies between allopatric and sympatric populations, and morph frequencies were not correlated between species across sympatric populations. Thus, common selective agents acting on the polymorphisms could not be demonstrated, although species-specific factors cannot be eliminated. It is possible that stochastic processes influence local morph frequencies, as has been suggested for $E$. ovata elsewhere.
\end{abstract}

Keywords: colour polymorphism, Enoplognatha, selection, spider, sympatric populations.

\section{Introduction}

The role of genetic drift in determining allele frequencies in natural populations has always been a controversial issue, particularly when visible variation is involved. In at least some cases, claimed examples of drift acting on visible morphs have, on closer examination, been found to involve local selective forces (e.g. Cain \& Sheppard, 1950). In other instances, however, it is highly likely that stochastic influences do have major effects on allele frequencies even though the morphs they control are visibly very distinct. One well studied example concerns the colour polymorphism in the spider Enoplognatha ovata (Clerck) (Oxford, 1983, 1989, and references therein $\rangle$. Three major morphs are recognized, lineata has a plain yellow/cream opisthosoma, redimita has superimposed on this a pair of dorsolateral carmine stripes, whereas ovata has a solid shield of carmine on the dorsal surface (Plate 1 in Oxford, 1983). The aim of much of this work has been to elucidate factors responsible for the maintenance of the visible polymorphism and for determining morph frequencies in natural populations. Although there are indications that selection is maintaining the polymorphism and influencing morph frequencies on a gross geographical scale (Oxford, 1985a), evidence for natural selection at a local level has been elusive, despite extensive observations and experiments (Oxford \& Shaw, 1986; Reillo \& Wise, 1988). This has led to the suggestion that stochastic processes play a major role in determining morph frequencies in local populations (Oxford, 1989; Oxford \& Shaw, 1986; Reillo \& Wise, 1988). Analyses of a further two polymorphisms, one regulating the colour locus, the other determining black spotting, re-inforce this interpretation (Oxford, 1985b, 1989). However, genetic drift is a default hypothesis and it is very difficult to eliminate entirely the influence of subtle and local selection on morph frequencies.

In their revision of the 'Enoplognatha ovata' group, Hippa \& Oksala (1982) described from continental material a sibling species, E. latimana, which possesses 
polymorphisms apparently homologous to those studied in E. ovata (Hippa \& Oksala, 1982; Oxford, 1991; Snazell, 1983). E. latimana has subsequently been found in a number of areas of Britain (Oxford, 1985a, 1991; Snazell, 1983). This situation opens up a further avenue through which to explore the possible action of weak natural selection in local populations. If visible morph frequencies in mixed species populations co-vary then, barring hybridization, natural selection alone must be responsible (Endler, 1986). However, the converse is not true; if species do not co-vary, selection acting in a species-specific manner cannot be dismissed. In the present paper, I examine morph frequencies in single- and mixed-species populations of $E$. ovata and E. latimana in an attempt to answer the following questions: (i) within a locality, do morph frequencies of a species differ between allopatric and sympatric populations? (ii) are morph frequencies correlated between species across sympatric populations?

\section{Methods}

Collections of mature females of both species were made in south-west Wales during early August 1990. From mid-July onwards, females establish themselves within rolled leaves where they produce and guard their egg cocoons. E. latimana matures slightly later than E. ovata (Oxford, 1991; Snazell, 1983) and the sampling was timed such that all females of both species should be within leaves, thus allowing an assessment of species composition within a site. Although virtually any broad-leaved plant can be used by the spiders, the vast majority of individuals were collected from bramble (Rubus fruticosus agg.). A small number of males was found associated with femalerolled leaves. Specimens were located by thoroughly searching an area for rolled leaves and then preserved in 70 per cent alcohol; E. ovata and E. latimana can only be distinguished reliably by means of microscopic examination. Since the red pigment of morphs redimita and ovata fades in alcohol, individuals were sorted for colour within $24 \mathrm{~h}$ of collection. Later, sex, species and spotting patterns were also scored. Samples had to be taken 'blind' without knowledge of species composition, but previous arachnological work helped to locate areas containing both species.

\section{Results}

In total, 33 samples were obtained from seven different geographical areas, Freshwater West (FW), Broad Haven $(\mathrm{BH})$, Orielton $\langle\mathrm{O})$, Freshwater East $(\mathrm{FE})$, West Angle Bay (WAB), Sawdern Point (SPt) and Manorbier
(MAN) (Fig. 1). E. latimana was found in all but one area, though not always in useful numbers (Table 1). Of the 1757 females collected, 1394 (79.3 per cent) were $E$. ovata, and although several sites were found to contain E. ovata alone, only one small sample (FW4, $N=16$ ) comprised only $E$. latimana. Fourteen males were also taken, four $E$. ovata and ten E. Latimana. Proportions of males in the two species differ significantly $\left(\chi_{(1)}^{2}=21.53, P<0.001\right)$. Males were not considered further.

Ignoring very small samples, the frequency of the lineata colour morph in $E$. ovata varied from 28 per cent at FE2 to 95 per cent at O1b. The majority of the rest were redimita except in FE2 where ovata made up $44 \pm 5$ per cent $(1 \mathrm{s.d}$.) of a large sample, the highest frequency of this morph recorded so far in Britain (Oxford, 1985a and unpublished). Indeed, the three FE sites nearby also had relatively high ovata frequencies of about 17 per cent. In E. latimana only the lineata and redimita morphs have been found to date (Oxford, 1991; Snazell, 1983). In the present samples, again ignoring those with small numbers, the frequency of lineata varied from 36 per cent at $\mathrm{BH} 3$ to 88 per cent at $\mathrm{O} 2 \mathrm{c}$.

\section{Variation within species within areas}

Within each of the seven areas, colour-morph, spotting and cocoon frequencies of each species were tested for heterogeneity between sites with a log likelihood ratio (G) test (Sokal \& Rohlf, 1981), or, where small samples from only two sites were involved, Fisher's exact test. Sites contributing to this heterogeneity were identified with a simultaneous test procedure (Sokal \& Rohlf, 1981: 728-730), again using $G$. Table 2 shows the results of these tests.

First consider the colour polymorphism. With the exception of Freshwater East samples, the majority of E. ovata were of the lineata or redimita colour morphs and so comparisons were made between proportions of lineata versus non-lineata. In all sites except for FW, SPt and MAN, significant differences were found, sometimes over very short distances. For example, O1b and $\mathrm{O} 1 \mathrm{c}$ are contiguous yet differ significantly in the frequency of the lineata and redimita morphs (Table 2). At Freshwater East, FE2 and FE4 are homogeneous with respect to lineata versus other colour morphs, and are significantly different from the other homogeneous group, FE1 and FE5 (the exclusion of FE4 from the latter group is very marginal). If one considers the ovata morph versus the rest then FE1, FE4 and FE5 are homogeneous and differ significantly from FE2. The distance between FE1 and FE2 is only about $80 \mathrm{~m}$. Fewer comparisons were possible between $E$. 


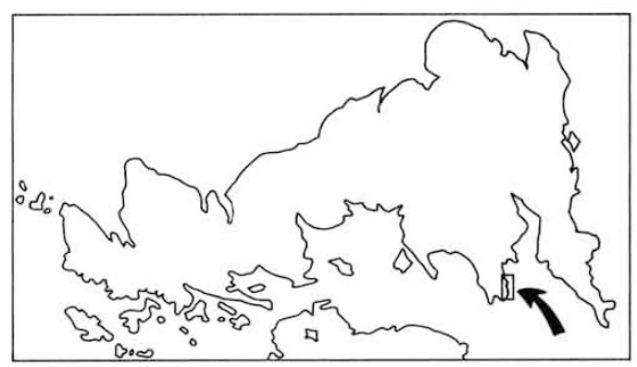

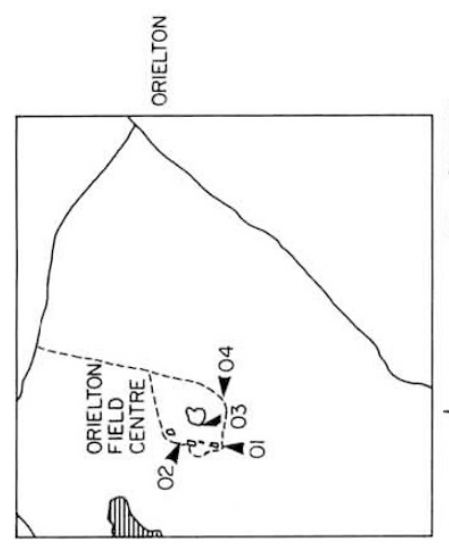
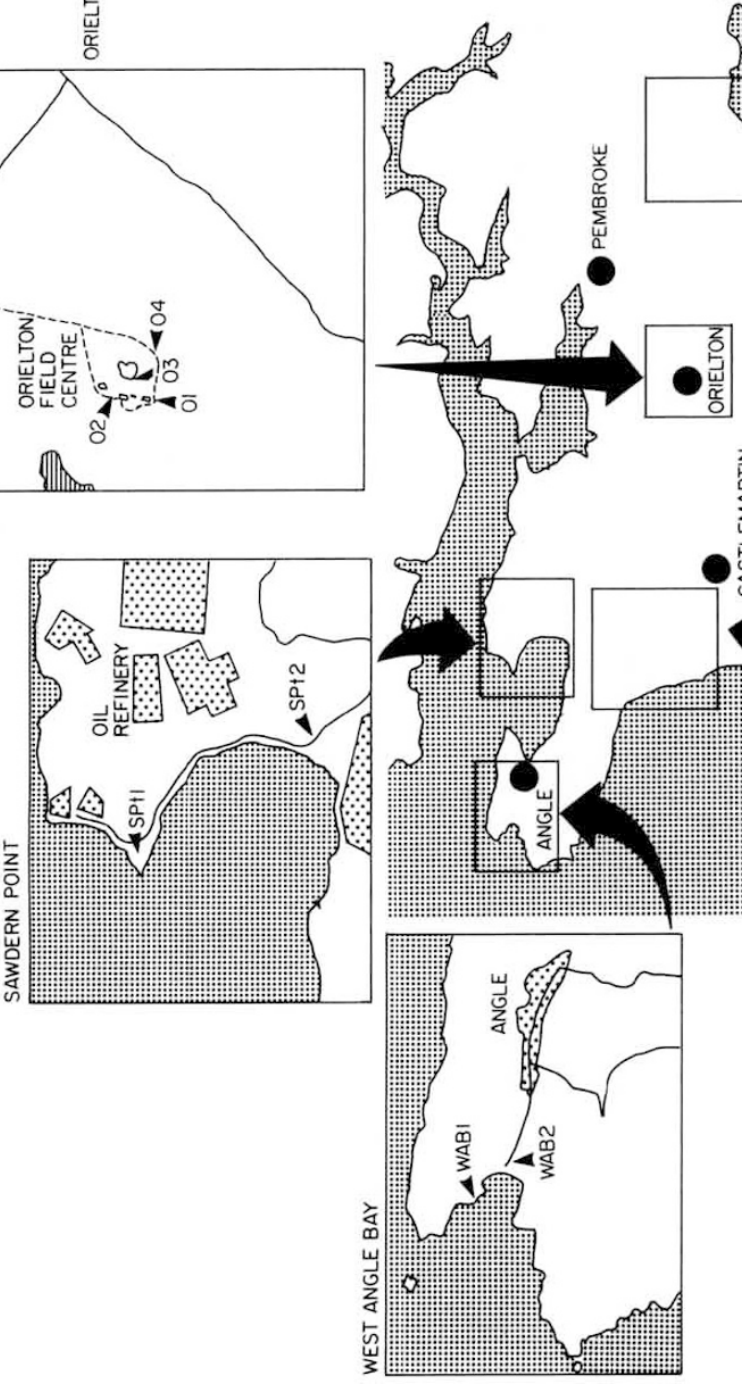

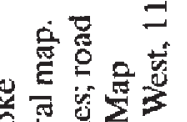

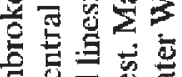

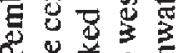

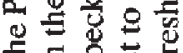

흐을

总昰官

w.

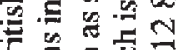

कृ

哥承的

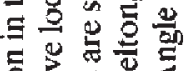

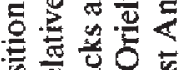

要要菏

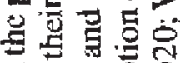

폴 흥

क ज

कू

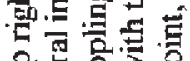

웅

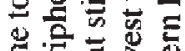

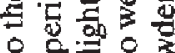

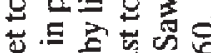

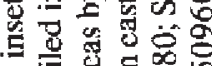

殏

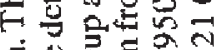

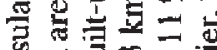

ह ह ल

它氖的

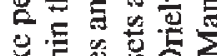

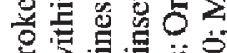

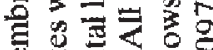

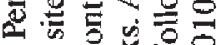

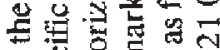

5 进

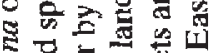

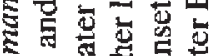

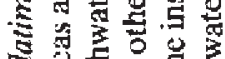

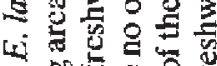

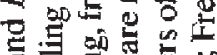

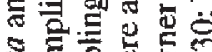

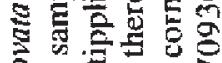

品家荡

的岂岕氙

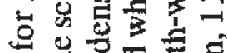

过司远

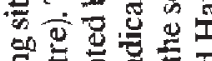

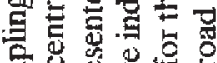

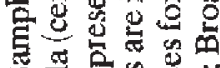

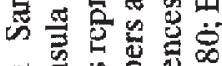

-

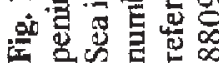


Table 1 Summary data from $E$. ovata and $E$. latimana populations. Sites distinguished only by a lower-case letter are contiguous. At Orielton site $\mathrm{O} 2 \mathrm{c}, 22$ individuals, specifically selected because they possessed cocoons, were omitted from the calculation of cocoon frequency. This was also the case for all individuals at site $\mathrm{O} 2 \mathrm{~d}$

\begin{tabular}{|c|c|c|c|c|c|c|c|c|c|c|c|c|}
\hline \multirow[b]{2}{*}{ Site } & \multicolumn{4}{|c|}{ Ovata } & \multicolumn{4}{|c|}{ Latimana } & \multirow[b]{2}{*}{$\% \mathbf{L}$} & \multicolumn{3}{|c|}{$c f . s p p$} \\
\hline & $\mathrm{N}$ & $\% \mathrm{Y}$ & $\% \mathrm{~S}$ & $\% \mathrm{C}$ & $\mathrm{N}$ & $\% \mathrm{Y}$ & $\% \mathrm{~S}$ & $\% \mathrm{C}$ & & $\mathrm{Col}$ & Spot & Coce \\
\hline \multicolumn{13}{|c|}{ Freshwater West } \\
\hline FW1 & 26 & 73.1 & 80.8 & 96.1 & 1 & 0 & 0 & 0 & 3.7 & ns & ns & ns \\
\hline FW2 & 77 & 61.0 & 70.1 & 84.4 & - & - & - & - & 0 & - & - & - \\
\hline FW3 & 8 & 100.0 & 50.0 & 100.0 & 65 & 60.0 & 0 & 21.5 & 89.0 & * & $* * *$ & $* * *$ \\
\hline FW4 & - & - & - & - & 16 & 75.0 & 18.7 & 43.7 & 100.0 & - & - & - \\
\hline FW5 & 7 & 42.9 & 71.4 & 85.7 & 29 & 44.8 & 6.9 & 37.9 & 80.5 & ns & $* * *$ & * \\
\hline FW6a & 48 & 72.9 & 85.4 & 89.6 & 3 & 100.0 & 33.3 & 33.3 & 5.9 & ns & ns & * \\
\hline FW6b & 61 & 67.2 & 75.4 & 72.1 & 2 & 100.0 & 50.0 & 50.0 & 3.2 & ns & ns & ns \\
\hline \multicolumn{13}{|c|}{ Broad Haven } \\
\hline BH1 & 74 & 63.5 & 75.7 & 85.1 & 7 & 71.4 & 28.6 & 57.1 & 8.6 & ns & $*$ & ns \\
\hline $\mathrm{BH} 2$ & 71 & 38.0 & 73.2 & 69.0 & - & - & - & - & 0 & - & - & - \\
\hline $\mathrm{BH} 3$ & 44 & 65.9 & 54.5 & 81.8 & 33 & 36.4 & 12.1 & 39.4 & 42.9 & $*$ & $* * *$ & $* * *$ \\
\hline $\mathrm{BH} 4$ & 12 & 66.7 & 58.3 & 100.0 & 2 & 50.0 & 0 & 100.0 & 14.3 & $\mathrm{~ns}$ & ns & ns \\
\hline $\mathrm{BH} 5$ & 57 & 80.7 & 80.7 & 98.2 & 41 & 56.1 & 21.9 & 39.0 & 41.8 & $* *$ & $* * *$ & $* * *$ \\
\hline \multicolumn{13}{|c|}{ Freshwater East } \\
\hline FE1 & 28 & 60.7 & 75.0 & 96.4 & 14 & 50.0 & 0 & 78.6 & 33.3 & ns & $* * *$ & ns \\
\hline FE2 & 123 & 28.4 & 49.6 & 78.9 & - & - & - & - & 0 & - & - & - \\
\hline FE3 & 6 & 33.3 & 66.7 & 100.0 & 6 & 66.7 & 0 & 66.7 & 50.0 & ns & ns & $\mathrm{ns}$ \\
\hline FE4 & 45 & 35.6 & 55.5 & 100.0 & 7 & 57.1 & 0 & 71.4 & 13.5 & ns & $* *$ & $*$ \\
\hline FE5 & 43 & 62.8 & 74.4 & 100.0 & - & - & - & - & 0 & - & - & - \\
\hline \multicolumn{13}{|l|}{ Orielton } \\
\hline Ola & 53 & 88.7 & 75.5 & 98.1 & - & - & - & - & 0 & - & - & - \\
\hline Olb & 46 & 95.5 & 58.7 & 95.6 & 2 & 100.0 & 0 & 50.0 & 4.2 & ns & ns & $\mathrm{ns}$ \\
\hline Olc & 28 & 67.8 & 75.0 & 96.4 & - & - & - & - & $0^{\dagger}$ & - & - & - \\
\hline $\mathrm{O} 2 \mathrm{a}$ & 25 & 84.0 & 68.0 & 88.0 & - & - & - & - & 0 & - & - & - \\
\hline $\mathrm{O} 2 \mathrm{~b}$ & 100 & 83,0 & 78.0 & 99.0 & 6 & 83.3 & 0 & 50.0 & 5.7 & ns & $* * *$ & $* * *$ \\
\hline $\mathrm{O} 2 \mathrm{c}$ & 131 & 84.6 & 71.7 & & 61 & 88.5 & 9.8 & & 31.8 & ns & $* * * *$ & \\
\hline & 115 & & & 98.3 & 55 & & & 41.8 & & & & $* * *$ \\
\hline $\mathrm{O} 2 \mathrm{~d}$ & 8 & 87.5 & 85.7 & - & 5 & 80.0 & 0 & - & 38.5 & $\mathrm{~ns}$ & $* *$ & - \\
\hline $\mathrm{O3}$ & 21 & 76.2 & 61.9 & 95.2 & 1 & 100.0 & 0 & 100.0 & 4.5 & $\mathrm{~ns}$ & ns & ns \\
\hline 04 & 83 & 92.8 & 73.5 & 95.2 & 4 & 100.0 & 25.0 & 50.0 & 4.6 & $\mathrm{~ns}$ & $\mathrm{~ns}$ & $*$ \\
\hline \multicolumn{13}{|c|}{ West Angle Bay, Sawdern Point and Manorbier } \\
\hline WAB1a & 11 & 90.9 & 72.7 & 63.6 & - & - & - & - & 0 & - & - & - \\
\hline WAB1b & 19 & 73.7 & 63.1 & 47.4 & - & - & - & - & 0 & - & - & - \\
\hline WAB2 & 40 & 47.5 & 85.0 & 85.0 & - & - & - & - & 0 & - & - & - \\
\hline SPt1 & 20 & 75.0 & 90.0 & 50.0 & 7 & 42.8 & 0 & 71.4 & 25.9 & ns & $* * *$ & ns \\
\hline $\mathrm{SPt} 2$ & 38 & 68.4 & 89.5 & 94.7 & 2 & 50.0 & 0 & 50.0 & 5.0 & ns & $*$ & ns \\
\hline MAN1 & 14 & 78.6 & 71.0 & 100.0 & 45 & 56.0 & 13.3 & 46.7 & 76.3 & ns & $* * *$ & $* * *$ \\
\hline MAN2 & 22 & 95.4 & 91.0 & 100.0 & 4 & 0 & 50.0 & 75.0 & 15.4 & $* * *$ & ns & ns \\
\hline
\end{tabular}

$N=$ sample size (females). $\% \mathrm{Y}=$ per cent yellow (lineata) colour morph. $\% \mathrm{~S}=$ per cent black-spotted morph. $\% \mathrm{C}=$ per cent with cocoons. $\% \mathrm{~L}=$ per cent $E$. latimana in sample. cf.spp = comparison of colour $(\mathrm{Col})$, spotting $($ Spot $)$ and cocoons $(\mathrm{Cocc})$ between species.

ns $\approx$ Non-significant. ${ }^{*}=0.01>P>0.05 .^{* *}=0.001>P>0.01 .^{* * *}=P<0.001$.

$\dagger=$ one male, but no female, E. latimana. 
Table 2 Comparisons of character frequencies between $E$. ovata populations within areas; lineata for colour, presence for spotting and cocoons. Only areas/ characters with significant heterogeneity are shown. For Freshwater East, the analysis was performed for both lineata $(\mathrm{L})$ and ovata $(\mathrm{O})$ colour morphs. Sites are arranged from left to right in order of increasing frequency of the character; those joined by a continuous line are not significantly different. Dotted lines indicate borderline cases (Freshwater East, lineata) or where tests could not be done

\begin{tabular}{|c|c|c|c|c|c|c|c|c|}
\hline $\begin{array}{l}\text { Freshwater W } \\
\text { Cocoons: }\end{array}$ & FW6b & FW2 & FW6a & FW1 & & & & \\
\hline $\begin{array}{l}\text { Broad Haven } \\
\text { Colour: }\end{array}$ & $\underline{\mathrm{BH} 2}$ & $\underline{\mathrm{BH} 1}$ & $\mathrm{BH} 3$ & $\mathrm{BH} 4$ & $\mathrm{BH} 5$ & & & \\
\hline Spots: & $\underline{\mathrm{BH} 3}$ & $\mathrm{BH} 4$ & $\mathrm{BH} 2$ & $\mathrm{BH} 1$ & BH5 & & & \\
\hline Cocoons: & $\mathrm{BH} 2$ & $\mathrm{BH} 3$ & $\mathrm{BH} 1$ & BH5 & $\mathrm{BH}_{4}^{4}$ & & & \\
\hline $\begin{array}{l}\text { Orielton } \\
\text { Colour: }\end{array}$ & O1c & $\mathrm{O} 3$ & $\mathrm{O} 2 \mathrm{~b}$ & $\mathrm{O} 2 \mathrm{a}$ & $\mathrm{O} 2 \mathrm{c}$ & $\mathrm{O} 1 \mathrm{a}$ & $\mathrm{O} 4$ & o1b \\
\hline $\begin{array}{l}\text { Freshwater Ea } \\
\text { Colour: (L) }\end{array}$ & t & FE4 & FE1 & FE5 & & & & \\
\hline (O) & FE5 & FE4 & FE1 & FE2 & & & & \\
\hline Spots: & FE2 & FE4 & FE5 & FE1 & & & & \\
\hline Cocoons: & $\underline{\mathrm{FE} 2}$ & FE1. & FE4 & FE5 & & & & \\
\hline $\begin{array}{l}\text { West Angle Ba } \\
\text { Colour: }\end{array}$ & WAB2 & WAB1b & WABla & & & & & \\
\hline Cocoons: & WAB1b & WABla & WAB2 & & & & & \\
\hline $\begin{array}{l}\text { Sawdern Point } \\
\text { Cocoons: }\end{array}$ & SPt1 & $\underline{\mathrm{SPt} 2}$ & & & & & & \\
\hline
\end{tabular}

latimana populations within areas and only one, between the two Manorbier sites, was significant $(P=0.0003$, Fisher's exact test $)$.

With regard to black spotting, heterogeneity was found between $E$. ovata populations in only two areas, Broad Haven and Freshwater East. At Broad Haven, the significantly dissimilar groupings are not those identified with respect to the colour polymorphism. At Freshwater East the groupings are the same as for lineata versus other colour morphs, mentioned above. For E. latimana, comparison between FW3, FW4 and FW5 yields a significant chi-squared value (since one observed value is zero, $G$ cannot be calculated, although the expected numbers of spotted individuals are small and will artificially inflate the overall chisquared value. If a comparison is made between sites with the highest (FW4) and lowest (FW3) frequency of the spotted morph, the difference is highly significant ( $P=0.006$, Fisher's exact test).

Finally, although the proportion of individuals with cocoons at the time of sampling is not a genetic trait, it can indicate environmental differences between sites which might have genetic implications. For E. ovata, heterogeneity between populations was found in five areas, Freshwater West, Broad Haven, Freshwater East, West Angle Bay and Sawdern Point. At West Angle Bay, the groups identified are the same as those for colour, while at Freshwater East, groups correspond to those recognized on the basis of frequency of the ovata colour morph. In other cases, groupings do not correspond. None of the small number of $E$. latimana comparisons within areas was significant.

\section{Variation within species between areas}

For $E$. ovata, one way analyses of variance on arcsine transformed data were used to investigate whether variation between areas in mean frequencies for the three measured characters was significant. Using all sites with sample sizes of 15 or more, $F$-values for colour (lineata), spotting and cocoons were all significant, although two were borderline $\langle P=0.003$, $P=0.04$ and $P=0.05$, respectively).

As noted above, with the exception of Manorbier sites, E. latimana collections were homogeneous for colour-morph frequencies within areas, so numbers of 
lineata and redimita were therefore summed. Comparisons between areas revealed highly significant differences $\left(\chi_{[4\}}^{2}=32.7\right.$ if Manorbier was included, $\chi_{[3\}}^{2}=30.3$ if it was not; $P<0.001$ in each case), ranging from 89 per cent lineata at Orielton to 49 per cent at Broad Haven. For spotting and for cocoons, comparisons between areas were also significant $\left\langle\chi_{(4)}^{2}=11.5\right.$, $0.01<P<0.05$, and $\chi_{(4)}^{2}=20.2, P<0.001$, respectively). Black-spotting frequency varied from zero at Freshwater East to 18 per cent at Broad Haven, while the frequency of spiders with cocoons ranged from 29 per cent at Freshwater West to 74 per cent at Freshwater East. Sawdern Point was excluded from all these analyses because of the small sample sizes.

\section{Associations between characters within species}

Associations were sought between pairwise combinations of colour (lineata vs. others), spotting and cocoons (presence/absence) within populations using $2 \times 2$ contingency tables. Significance was assessed with chi-squared when numbers were large and with Fisher's exact test when numbers were small, which they usually were. In 108 separate tests, involving both species, only one was formally significant. Trends among contingency tables were tested using Cochran's $Y$ statistic (Everitt, 1977). Out of the six tests (three pairwise comparisons $\times$ two species) that for spotting vs. cocoons in $E$. ovata was highly significant ( $Y=3.54$, $P=0.0004$, number of populations $(n)=24$ ), suggesting that spiders with spots were more likely to have cocoons at the time of sampling. The corresponding comparison in E. latimana showed a trend in the same direction but was not significant $(Y=1.52, P=0.12$, $n=7$ ). No trends were shown in either species for comparisons of colour and spotting. Colour vs. cocoons showed no trend for $E$. ovata, but for $E$. latimana it was just significant ( $Y=2.06, \quad P=0.04, n=13$ ), suggesting that individuals of the lineata morph were more likely to have had cocoons when sampled. To explore further the relationship between spotting and cocoons in E. ovata, those spiders with spots were cross-classified according to whether they were with or without a cocoon and whether they fell above or below the median spot number for all spotted individuals within a sample. Even numbers of spiders falling in the median spot class were divided equally between the above and below categories; for odd numbers, one individual was omitted. Only 16 populations could be used and many of these had zeros or very small numbers in one or more cells of the contingency table. None of the tests was individually significant and there was no discernible trend among populations $(Y=-0.60)$.

\section{Associations between species within sites}

Tests were also made to investigate whether there were significant differences between the two species when living sympatrically. The results of analysing frequencies of colour, spotting and cocoons in $2 \times 2$ contingency tables, using chi-squared or Fisher's exact tests, are indicated in Table 1. In many cases numbers of one of the species are small, and the power of the test will consequently be reduced. For colour, out of 22 comparisons two were formally significant at the 5 per cent level, one at the 1 per cent and one at the 0.1 per cent level. In all four cases E. latimana had a lower frequency of the lineata morph than $E$. ovata, although other populations do not support this trend. In five sites (BH3, BH5, O2c, FE1 and MAN1) numbers of both species were relatively large while in five others (FW3, FW5, BH1, FE4 and SPt1) one or other species was represented by only seven or eight individuals. Correlations of lineata morph frequencies (after arcsine transformation) in the two species in all ten sites, or in just those five with appreciable numbers, were not significant $(r=0.291$ and $r=0 \cdot 752$, respectively).

For spotting, every one of the 22 samples containing both species showed E. latimana to have fewer spots, and this is formally significant in 13 comparisons, nine at the 0.1 per cent level. Correlations of arcsinetransformed frequencies of spotted individuals in the two species in all ter, or in the five larger, populations are not significant $\langle r=0.167$ and $r=-0.020$, respectively $)$.

A similar situation obtains when cocoons are considered. In all but three sites, E. latimana had a lower proportion of cocoons at the time of sampling; two of the exceptions were samples with only one or two $E$. latimana individuals, the third had seven (SPt1). Ten of the comparisons were significant, six at the 0.1 per cent level. Correlations of transformed cocoon frequencies between species were not significant $(r=-0.290$ and $r=0.083$, for 10 and for five populations, respectively).

\section{Discussion}

The extensive heterogeneity in colour-morph frequency in $E$. ovata, identified both within and between the seven areas examined here, comes as no surprise. Microgeographical differentiation is one of four features common to most studies of colour variation in this species; the other three are: (i) the ubiquity of the polymorphism; (ii) the consistent rank order of colour morphs within populations i.e. ineata $>$ redimita $>$ ovata; and (iii) the temporal stability of morph frequencies within populations (Bristowe, 1931; Hippa 
\& Oksala, 1979; Oxford, 1985a, 1976; Oxford \& Shaw, 1986; Reillo, 1989; Reillo \& Wise, 1988; Wise \& Reillo, 1985). Unfortunately, fewer comparisons were possible for E. latimana and sample sizes were generally lower, but this species too shows highly significant differences in colour-morph frequencies between areas and in some cases over shorter distances within areas (e.g. FW3, 4 and 5). The range of morph frequencies in medium to large samples is comparable in the two species.

A similar, but less marked, situation obtains with regard to black-spotting. In $E$. ovata, differences in morph frequencies between areas were at best only marginally significant and there was less evidence for heterogeneity within areas (Table 2). Only two other studies have investigated this trait in natural populations. At seven Norfolk sites, distributed within an area of $c .10 \mathrm{~km}^{2}$, spotting frequencies were very similar to one another (range 92-100 per cent) (Oxford, 1991). In Nidderdale, Yorkshire, there were marked differences in spotting between sites, but possibly over a larger geographical scale than that shown by the colour morphs (Oxford, 1989). For spotting, patterns of variation in E. latimana again resemble those in $E$. ovata with indications of heterogeneity in spotting frequency within one area (Freshwater West) and significant differences between areas.

The geographical heterogeneity in both colour pattern and spotting makes it much harder to approach the first question posed in the introduction, i.e. within a locality, do morph frequencies within a species differ between allopatric and sympatric populations? The problem is exacerbated by the fact that the majority of populations sampled contain both species, although often with one at low frequency. Bearing in mind the very small number of comparisons available, inspection of Table 1 does not suggest consistent morphfrequency shifts between single- and mixed-species populations.

Comparisons of colour, spotting and cocoon frequencies between species within sympatric populations revealed some differences with respect to colour but highly significant differences for spotting and cocoons. Four out of 22 populations showed significant differences for colour, all in the direction of $E$. ovata having a higher frequency of the lineata morph. However, lack of a similar trend in other populations urges caution in interpreting this result. Colour-morph frequencies are not correlated between species, although the number of suitable sympatric populations is not large. For spotting, E. latimana had the lower frequency in all 22 comparisons. This observation is consistent with the tentative conclusion of Snazell (1983), based on material from Dorset, and with data from sympatric populations in Norfolk (Oxford, 1991). It appears that, in Britain at least, $E$. latimana generally has a lower frequency of spotting than $E$. ovata, although populations of the latter can vary widely in this respect (Oxford, 1989). Spotting frequencies for the two species in the present populations are not correlated.

The highly significant differences between numbers of $E$. ovata and $E$. latimana females with cocoons were expected. An earlier maturation of $E$. ovata was suggested by Hippa \& Oksala (1982) and Snazell (1983), and confirmed and quantified by Oxford (1991). This difference in phenology is also indicated by the higher number of E. latimana males recorded, despite lower numbers of this species overall. Males die soon after mating. Within species, differences in cocoon frequency, both between populations and between areas, probably reflect aspects of the environment such as food availability, insolation etc. Surprisingly, therefore, cocoon frequencies in sympatric populations were not correlated between the species. This might reflect the small sample size, speciesspecific ecological factors, or both.

In E. ovata, there was a highly significant trend for females with cocoons to have black spots, although this was not statistically discernible within individual populations. A similar, but non-significant, trend was suggested by the much sparser $E$. latimana data. It is possible that the presence of spots advances reproductive maturity through the heat gathering properties of the black pigment, a phenomenon well studied in a variety of invertebrates (e.g. Digby, 1984). If this is the case, however, one might expect those females with fewer spots to be less well advanced, as judged by cocoon production, than those with more. There was no evidence of this in the present case. Whether the association between spotting and rate of maturation is detected in populations elsewhere remains to be seen.

In conclusion, the large amount of variability in morph frequencies exhibited by both $E$. ovata and $E$. latimana in the area studied makes comparisons between species difficult. For $E$. ovata, evidence for local selection acting on colour is lacking despite substantial efforts to detect it (Oxford \& Shaw, 1986; Reillo \& Wise, 1988, see also Oxford, 1989). These authors have suggested a major role for intermittent drift in determining colour-morph frequencies in local populations. By extension, the same process might also be important in E. latimana. A similar argument also applies to black spotting (Oxford, 1989). Very local, species-specific, selection cannot be eliminated for either species, but in other populations of $E$. ovata this seems unlikely (Oxford \& Shaw, 1986; Reillo \& Wise, 1988). There is no evidence in the present morph- 
frequency data to suggest interactions between the species or systematic changes in sympatric populations which would have been indicative of a common selective agent, but obviously more data are required to check these tentative conclusions. To some extent, patterns of morph-frequency variation in the two Enoplognatha species resemble those found in the land snails Cepaea nemoralis and C. hortensis. In Cepaea the frequencies of identical visible morphs often differ within sympatric populations and in at least some cases this is a result of a species-specific response to the same visual selective force (e.g. Clarke, 1960, 1962).

Finally, the patterns of morph-frequency variation observed mean that possible gene exchange between species is not a contributory factor. In any case, a smallscale electrophoretic investigation in the Orielton populations revealed diagnostic markers for the species, and no evidence of hybridization (G. S. Oxford, unpublished).

\section{Acknowledgements}

I thank the British Ecological Society for financial support, the staff of Orielton Field Studies Centre for hospitality, members of the British Arachnological Society, and in particular Stan Dobson, for initially locating many of the mixed species areas, and Terry Crawford for comments on the manuscript. Bob Haycock (Nature Conservancy Council) kindly gave permission to collect the Broad Haven samples on Stackpole National Nature Reserve.

\section{References}

BRISTOWE, w. S. 1931. Notes on the biology of spiders - V. Theridion ovatum, Clerck, its habits and varieties. Ann. Mag. Nat. Hist., 8, 466-469.

CAIN, A. J. AND SHEPPARD, P. M. 1950. Selection in the polymorphic land snajl Cepaea nemoralis. Heredity, 4, 275-294.

CLARKE, B. C. 1960. Divergent effects of natural selection on two closely-related polymorphic snails. Heredity, 14, 423-443.

CLARKE, B. C. 1962 . Natural selection in mixed populations of two polymorphic snails. Heredity, 17, 319-345.

DIGBY, P. S. B. 1984. Factors affecting the temperature excess of insects in sunshine. J. Exp. Biol, 32, 279-298.
ENDter, J. A. 1986. Natural Selection in the Wid. Princeton University Press, New Jersey.

EVERITT, B. \$. 1977. The Analysis of Contingency Tables. Chapman and Hall, London.

HIPPA, H. AND OKSALA, I. 1979. Colour polymorphism of Enoplognatha ovata (Clerck) (Araneae, Theridiidae) in Western Europe. Hereditas, 90, 203-212.

HIPPA, H. AND OKSALA, I. 1982, Definition and revision of the Enoplognatha ovata (Clerck) group (Araneae: Theridiidae). Ent. Scand., 13, 213-222.

OXFORD, G. $s .1976$. The colour polymorphism in Enoplognatha ovatum (Clerck) (Araneae: Theridiidae) - Temporal stability and spatial variability. Heredity, 36, 369-381.

OXFORD, G. S. 1983. Genetics of colour and its regulation during development in the spider Enoplognatha ovata (Clerck) (Araneae: Theridiidae). Heredity, 51, 621-634.

OxFord, G. s. 1985a. A countrywide survey of colour morph frequencies in the spider Enoplognatha ovata (Clerck) (Araneac: Therididae): evidence for natural selection. Biol. J. Linn. Soc., 24, 103-142.

OXFORD, G. S. 1985 b. Geographical distribution of phenotypes regulating pigmentation in the spider Enoplognatha ovata (Clerck) (Araneae: Theridiidae). Heredity, 55, 37-45.

OXFORD, G. S. 1989. Genetics and distribution of black spotting in Enoplognatha ovata (Araneae: Theridiidae), and the role of intermittent drift in population differentiation. Biol. J. Linn. Soc, 36, 111-128.

OXFORD, G. \$. 1991. Enoplognatha ovata and E. latimana: A comparison of their phenologies and genetics in Norfolk populations. Bull. Br. Arachnol. Soc. (in press).

OXFORD, G. S. AND SHAW, M. w. 1986. Long-term variation in colour-morph frequencies in the spider Enoplognatha ovata (Araneae: Theridiidae): natural selection, migration and intermittent drift. Biol. J. Linn. Soc., 27, 225-249.

REILlo, P. R. 1989. Color polymorphism in the spider Enoplognatha ovata (Araneae: Theridiidae): Broad-scale morph-frequency variation in northeastern North America. Am. Midl. Nat., 122, 199-203.

REILLO, P. R. AND WSE, D. H. 1988. An experimental evaluation of selection on colour morphs of the polymorphic spider Enoplognatha ovata (Araneae: Theridiidae). Evolution, 42, 1172-1189.

SNAZELL, R. 1983. On two spiders recently recorded from Britain. Bull. Br. Arachnol. Soc, 6, 93-98.

SOKAL, R. R. AND ROHLF, F. J. 1981. Biometry, 2nd edn, W. H. Freeman \& Co., San Francisco.

WISE, D. H. and REILLO, P. R. 1985. Frequencies of color morphs in four populations of Enoplognatha ovate (Araneae: Theridiidae) in eastern North America. Psyche, 92, 135-144. 